\title{
Pengembangan Buku Teks Pembelajaran Matematika Berbasis IT Berbahasa Inggris untuk Meningkatkan Hasil Belajar Kalkulus Mahasiswa TMT IAIN Tulungagung
}

\author{
${ }^{1}$ Dewi Asmarani, ${ }^{2}$ Nany Suengkono Madayani \\ ${ }^{1}$ Program Studi Tadris Matematika, FTIK, IAIN Tulungagung \\ JI. Mayor Sujadi Timur No.46 Tulungagung, 66221, Indonesia \\ E-mail: ${ }^{1}$ dewiasmarani.iain@gmail.com
}

Article History:

Received: $x x-x x-x x x x$; Received in revised form: $x x-x x-x x x x$; Accepted: $x x-x x-x x x x$;

Available online: $\mathrm{xx}-\mathrm{xx}-\mathrm{xxxx}$

\begin{abstract}
Awareness of the importance of English is not fully understood by students. therefore a tool is needed to help them. The tools used are textbooks. This study tries to develop an IT-based mathematics textbook. the existence of the book is expected to improve their English and mathematical skills. Textbooks are developed through 4 stages of development, namely: the definition stage, the design stage, the development stage, and the dissemination phase. After going through four stages are then acquired IT-based mathematics textbooks are valid and effective. Based on the assessment of two validators obtained validity of 3.30. This shows that, the IT-based mathematics textbook has met valid criteria. while students who get more than 80 are $90.06 \%$. Thus the value is included in the completeness criteria.
\end{abstract}

Keywords: Textbook Development; Mathematics Textbook IT-Based in English; Learning Outcomes of Mathematics.

\begin{abstract}
Abstrak
Kesadaran akan pentingnya berbahasa Inggris belum sepenuhnya di pahami oleh mahasiswa. oleh sebab itu diperlukan alat bantu untuk membantu mereka. Alat bantu yang diusahakan berupa buku teks. Penelitian ini mencoba mengembangkan sebuah buku teks matematika berbasis IT. dengan adanya buku tersebut diharapkan dapat meningkatkan kemampuan berbahasa inggris dan matematikanya. Buku teks dikembangkan melalui 4 tahap pengembangan yaitu: tahap definisi, tahap desain, tahap pengembangan, dan tahap pendiseminisian. Setelah melalui keempat tahapan tersebut maka diperoleh buku teks matematika berbasis IT yang valid dan efektif. Berdasarkan penilaian dua orang validator diperoleh kevalidan sebesar 3,30. Hal ini menunjukkan bahwa, Buku teks matematika berbasis IT tersebut telah memenuhi kriteria valid. sedangakan mahasiswa yang mendapat nilai lebih dari 80 adalah 90.06\%. Dengan demikian nilai tersebut masuk dalam kriteria ketuntasan.
\end{abstract}

Kata Kunci: Pengembangan Buku Teks; Buku Teks Matematika Berbasis IT Berbahasa Inggris; Hasil Belajar Matematika. 


\section{Pendahuluan}

Penerapan bahasa inggris di dunia Internasional dianggap cukup berhasil. Menurut survei M. Paul lewis pada part of ethnologue bahwa pada tahun 2009 bahasa Inggris menempati peringkat ke - 3 sebagai bahasa yang mendominasi di negara-negara di dunia dari total 172 bahasa yang tercatat 1 . Bahasa Inggris digunakan oleh 328 juta pengguna dari 112 negara di dunia. Berdasarkan hasil survei tersebut dapat disimpulkan bahwa bahasa Inggris adalah bahasa dunia yang seharusnya dikuasai oleh kebanyakan orang di dunia.

Di Indonesia bahasa Inggris menjadi salah satu muatan bahasa wajib di setiap jenjang sekolah (SD,SMP/SLTP,SMA/SLTA) sebagai penunjang kompetensi literasi siswa. Dengan adanya kebijakan tersebut, hendaknya semua sekolah diwajibkan menyertakan mata pelajaran bahasa Inggris ke dalam muatan kurikulumnya.

Hasil survei yang dilakukan oleh salah satu mahasiswa International bipolar Foundation (IPBF) tentang pentingnya bahasa Inggris dalam meningkatkan daya saing setelah lulus menunjukkan dari 196 responden, 195 respondennya menjawab bahwa bahasa Inggris memang penting untuk meningkatkan daya saing setelah lulus ${ }^{2}$ Hal ini menunjukkan bahwa bahasa Inggris memang benar-benar sangat dibutuhkan.

Kesadaran akan pentingnya berbahasa Inggris ini tampaknya belum sepenuhnya di pahami oleh mahasiswa yang belum lulus kuliah. Dalam hal ini khususnya mahasiswa jurusan Tadris matematika (TMT) IAIN Tulungagung. Hal ini terbukti dari hasil survei peneliti yang menunujukkan dari 320 responden, 80\% mahasiswa merasa keberatan juga kesulitan ketika literatur yang dipakai menggunakan bahasa inggris. Kondisi seperti ini tentu saja sempat membuat peneliti sebagai dosen TMT merasa prihatin sebab matematika itu penting. Oleh karena itu sebagai calon-calon guru matematika, hendaknya selain menguasai matematika, mereka juga harus

1 Nicholas Abercrombie, Stephen Hill, and Bryan S. Turner, Kamus Sosiologi (Yogyakarta: Pustaka Pelajar, 2010).

2 Rahma Sugihartati and Fitri Mutia, "Masyarakat Dan Perpustakaan Di Era Revolusi Informasi," Surabaya: Departemen IIP FISIP Universitas Airlangga, 2010. 


\section{Pengembangan Buku Teks Pembelajaran..}

mampu menyampaikan matematika tersebut dengan menggunakan dua bahasa, yaitu bahasa Inggris dan bahasa Indonesia.

Menurut Hudodjo matematika adalah sekumpulan ide-ide abstrak yang tersusun menjadi suatu konsep-konsep dengan penalaran deduktif formal ${ }^{3}$ Kemudian matematika ini disampaikan ke dalam suatu pembelajaran yang disebut pembelajaran matematika. Pembelajaran matematika adalah proses interaksi yang terjadi antara guru dan siswa di dalam kelas dimana siswa mengkonstruk sendiri pengetahuannya tentang konsep-konsep abstrak yang diterimanya. Hal ini sesuai dengan pandangan para ahli konstruktivisme yang menyatakan belajar adalah aktivitas yang dilakukan siswa untuk menemukan sendiri konsep yang dipelajarinya 4

Matematika juga berperan penting dalam proses kehidupan manusia. Dalam kehidupan sehari-hari kita tidak akan terlepas dari matematika, baik dari hal yang kecil sampai pada perkembangan teknologi yang canggih. Hal ini diperkuat oleh Peterson dalam Berch dan Mazzocco mengemukakan bahwa "math is indeed very useful and thus important "5. Pernyataan tersebut berarti bahwa matematika itu sangat berguna dan penting. Oleh sebab itu penting kiranya bagi setiap orang untuk menguasainya.

Namun kenyataannya di lapangan menunjukkan bahwa matematika masih dianggap sulit dan abstrak, dan membosankan. Bahkan ada yang menganggap matematika adalah suatu pelajaran yang menakutkan dan hanya dapat dipahami oleh orang-orang tertentu saja 6 Kesulitan ini juga terjadi ditingkat perguruan tinggi. Khususnya di kampus IAIN Tulungagung. Dari hasil wawancara penulis dengan beberapa orang mahasiswa pada bulan april tahun 2017 diperoleh fakta bahwa mahasiswa sering kali merasa

\footnotetext{
${ }^{3}$ Herman Hudojo, Pengembangan Kurikulum Dan Pembelajaran Matematika (Malang: Universitas Negeri Malang Press, 2005).

4 Sardiman. A.M, Interaksi \& Motivasi Belajar Mengajar (Jakarta: Raja Grafindo Persada, 2006).

5 Daniel B. Berch and Michele M. M. Mazzocco, eds., Why Is Math So Hard For Some Children?: The Nature and Origins of Mathematical Learning Difficulties and Disabilities, 1 edition (Baltimore, Md: Brookes Publishing, 2007).

${ }^{6}$ Anggraini Titis, "Pengembangan Media Pembelajaran Interaktif Dengan Macromedia Flash Pada Materi Garis Dan Sudut Untuk SMP Kelas VII" (Tesis, Universitas Negeri Malang, 2013).
} 
bingung dan kesulitan ketika dihadapkan pada mata kuliah Limit dan Integral. Limit dan integral dalam jurusan matematika disajikan dalam matakuliah Kalkulus.

Salah satu upaya untuk mengatasi kesulitan mahasiswa tersebut adalah pihak jurusan menyajikan sebuah matakuliah baru yang diharapkan membantu mahasiswa dalam memahami konsep-konsep matematika melalui belajar matematika berbasis IT. Aktivitas ini sangatlah penting karena Teknologi Informasi dan Komunikasi (TIK) telah berkembang menyentuh di segala aspek kehidupan manusia. Perkembangan teknologi komputer sangat pesat tidak hanya mampu mengolah data tetapi juga dapat membantu dalam kegiatan pembelajaran. Di bidang pendidikan komputer dimanfaatkan sebagai salah satu alternatif dalam penggunaan media pembelajaran.

Perkembangan komputer saat ini, telah mengubah konsep multimedia. Pada jaman dahulu, kata multimedia dapat diartikan sebagai kombinasi dari berbagai media yang berbeda untuk digunakan presentasi. Akan tetapi sekarang ini multimedia dimaknai sebagai transmmiting text, audio dan graphics inreal time. Makna yang lebih luas, menurut Gayestika komputer sebagai alat multimedia interaktif memiliki berbagai macam kegunaan sebagai alat bantu untuk tutorial interaktif dan pedoman elektronik 7

Beberapa penelitian terdahulu terutama tentang pengembangan bahan ajar telah dilakukan diantaranya Pengembangan Bahan Ajar Berbasis Komputer dalam Pembelajaran Matematika Pada Pokok Bahasan Kubus dan Balok $^{8}$, Pengembangan Bahan Ajar Berbasis Komputer dalam Pembelajaran Matematika Pada Pokok Bahasan Lingkaran untuk kelas VIII Sekolah Menengah Pertama9, dan Pengembangan Bahan Ajar Online Mata Kuliah Micro Teaching dengan Model Borg \& Gall Pada Program S1 Pendidikan

\footnotetext{
7 Titis.

8 Ianah Ianah and Hendri Raharjo, "Pengembangan Bahan Ajar Berbasis Komputer Dalam Pembelajaran Matematika Pada Pokok Bahasan Kubus Dan Balok," Eduma: Mathematics Education Learning and Teaching 3, no. 2 (November 14, 2014), https://doi.org/10.24235/eduma.v3i2.59.

9 Malalina Malalina and Nila Kesumawati, "Pengembangan Bahan Ajar Interaktif Berbasis Komputer Pokok Bahasan Lingkaran Untuk Kelas VIII Sekolah Menengah Pertama," Jurnal Pendidikan Matematika 8, no. 1 (2014): 55-70, https://doi.org/10.22342/jpm.8.1.1861.55-70.
} 


\section{Pengembangan Buku Teks Pembelajaran..}

Bahasa Inggris STKIP Agama Hindu Singaraja10. Berdasarkan hal tersebut, pengembangan buku teks untuk meningkatkan hasil belajar mahasiswa sangat solutif terlebih lagi dikaitkan dengan IT berbahasa inggris.

Buku teks merupakan buku sekolah yang ditujukan untuk siswa pada jenjang tertentu, memuat materi yang sistematis terseleksi oleh pakar di bidangnya untuk maksud dan tujuan instruksional, dilengkapi dengan sarana pembelajaran yang mudah dipahami oleh pemakaiannya, sehingga dapat menunjang program pembelajaran ${ }^{11}$. Buku teks ini perlu kita kembangkan agar sesuai dengan perkembangan kurikulum. Pengembangan buku teks berarti mengajarkan suatu mata pelajaran melalui tulisan. Menurut Sungkono, dkk terdapat tiga cara mengembangkan buku teks, yaitu menulis sendiri, pengemasan kembali informasi, dan penataan informasi ${ }^{12}$.

Berdasarkan uraian tersebut maka peneliti merasa perlu mengembangkan suatu bahan ajar yang dapat membantu aktivitas belajar matematika mahasiswa. Bahan Ajar tersebut berupa buku teks. Buku teks dirancang dengan model bahasa Inggris. Buku teks ini diharapkan dapat membantu tutorial belajar Kalkulus dan bahasa Inggris secara elektronik.

\section{Metode}

Jenis penelitian yang dipilih adalah penelitian pengembangan. Sedangkan pendekatannya adalah pendekatan kualitatif. Populasi penelitiannya adalah mahasiswa Tadris Matematika IAIN Tulungagung semester empat yang terdiri dari enam kelas A, B, C, D, E, dan F. Keenam kelas ini digunakan sebagai sampel ujicoba baik ujicoba kelompok kecil maupun ujicoba kelompok besar. Adapun instrumen yang digunakan adalah lembar validasi, lembar tes, dan lembar angket. Untuk teknik pengumpulan

10 Gede Agus A. rya Saputra Yasa, "Pengembangan Bahan Ajar Online Mata Kuliah Micro Teaching dengan Model Borg \& Gall pada Program S1 Pendidikan Bahasa Inggris STKIP Agama Hindu Singaraja," Jurnal Ilmiah Pendidikan dan Pembelajaran Ganesha 1, no. 1 (2012), https://www.neliti.com/id/publications/207120/pengembangan-bahan-ajaronline-mata-kuliah-micro-teaching-dengan-model-borg-gall.

11 Menteri Pendidikan Nasional RI, "Peraturan Menteri Pendidikan Nasional Republik Indonesia Nomor 2 Tahun 2008 tentang Buku" (Biro Hukum dan Organisasi Departemen Pendidikan Nasional, January 4, 2008), http://kelembagaan.ristekdikti.go.id/wpcontent/uploads/2016/12/Isi-Permendiknas-2-thn-2008.pdf.

12 Sungkono, Pengembangan Bahan Ajar (Yogyakarta: FIP UNY, 2003).

\section{Al-Khwarizmi - 71}


datanya meliputi teknik validasi angket dan tes. Analisis data dalam pengembangan buku teks ini adalah kualitatif dan kuantitatif. Data kualitatif diperoleh dari kritik dan saran dari validator sedangkan data kuantitatif diperoleh dari angket.

\section{Deskripsi Pengembangan Buku Teks Matematika}

1. Hasil Validasi Ahli

Hasil validasi produk dengan menggunakan angket validasi yang diberikan kepada validator dan diperoleh hasil sebagai berikut.

Tabel 1. Hasil Validasi Ahli Materi

\begin{tabular}{|c|c|c|c|c|}
\hline \multirow{2}{*}{$\mathrm{N}$} & \multirow{2}{*}{ Aspek yang dinilai } & \multicolumn{2}{|c|}{ Validator ke- } & \multirow{2}{*}{$A_{i}$} \\
\hline & & 1 & 2 & \\
\hline & Bahasa Lugas & 3 & 3 & 3 \\
\hline 2. & Bahasa komunikatif & 3 & 3 & 3 \\
\hline 3. & Bahasa mudah dipahami & 3 & 3 & 3 \\
\hline & $\begin{array}{l}\text { Bahasa sesuai dengan sifat bahasa } \\
\text { matematika }\end{array}$ & 3 & 4 & 3,5 \\
\hline 5. & $\begin{array}{l}\text { Istilah dan simbol yang digunakan } \\
\text { konsisten. }\end{array}$ & 3 & 4 & 3,5 \\
\hline & Sesuai dengan kaidah bahasa & 4 & 4 & 4 \\
\hline & $\sum A_{i}$ & & & 20 \\
\hline & $R T V$ & & & 3.3 \\
\hline
\end{tabular}

Berdasarkan Tabel 1 tersebut, rata-rata penilaian dari dua orang validator terhadap buku teks matematika berbasis IT adalah sebesar 3,3. Hal ini menunjukkan bahwa, buku teks matematika berbasis IT tersebut telah memenuhi kriteria kevalidan yaitu berada pada rentang $3 \leq R T V=\leq 4$.

2. Efektivitas Buku Teks Matematika

Telah dikemukakan sebelumnya bahwa, keefektifan Buku Teks Matematika berbasis IT ditentukan oleh 2 hal, yaitu Tes dan respon mahasiswa terhadap pembelajaran dengan menggunakan Buku Teks Matematika berbasis IT.

Rekapitulasi hasil Tes mahasiswa seluruh kelas disajikan pada Tabel 2 berikut: 
Tabel 2. Rekapitulasi Hasil Tes

\begin{tabular}{cccc}
\hline & Kelas kecil & $\begin{array}{c}\text { Kelas } \\
\text { besar }\end{array}$ & $\begin{array}{c}\text { Persentase } \\
\text { rata-rata }\end{array}$ \\
\hline $\begin{array}{c}\text { Persentase Jumlah } \\
\text { mahasiswa yang mendapat } \\
\text { nilai lebih dari 80 }\end{array}$ & $87.5 \%$ & $92.62 \%$ & $90.06 \%$ \\
\hline
\end{tabular}

Berdasarkan Tabel 2 tersebut, jumlah mahasiswa yang mendapat nilai lebih dari 80 untuk kelas kecil adalah 87.5\% sedangkan untuk kelas besar mencapai 92.62\%. Sehingga jika diambil rata-rata dari keduanya maka mahasiswa yang mendapat nilai lebih dari 80 adalah 90.06\%. Dengan demikian nilai tersebut masuk dalam kriteria ketuntasan.

Rekapitulasi hasil angket respon mahasiswa seluruh kelas disajikan pada Tabel 3 berikut:

Tabel 3. Rekapitulasi Hasil Angket Respon Mahasiswa

\begin{tabular}{cccc}
\hline & Kelas kecil & $\begin{array}{c}\text { Kelas } \\
\text { besar }\end{array}$ & $\begin{array}{c}\text { Persentase } \\
\text { rata-rata }\end{array}$ \\
\hline $\begin{array}{c}\text { Persentase Jumlah } \\
\text { mahasiswa yang member } \\
\text { respon positif }\end{array}$ & $80.5 \%$ & $85.66 \%$ & $83.08 \%$ \\
\hline
\end{tabular}

Berdasarkan Tabel 3, jumlah mahasiswa yang memberikan respon positif terhadap Buku teks matematika berbasis IT untuk kelas kecil adalah 80.5\% sedangkan untuk kelas besar mencapai 85.66\%. sehingga jika diambil rata-rata dari keduanya maka mahasiswa yang memberikan respon positif terhadap Buku teks matematika berbasis IT adalah 83.08\%. dengan demikian nilai tersebut masuk dalam kriteria positif. Berdasarkan kriteria kevalidan dan keefektifan dapat dinyatakan bahwa Buku teks matematika berbasis IT memenuhi kriteria valid dan efektif.

Selama proses penyusunan Buku teks matematika berbasis IT ini banyak hal yang harus diperbaiki oleh penulis. Berdasarkan tabel penilaian validator menunjukkan bahwa hasil penilaian terhadap Buku teks matematika berbasis IT adalah sebesar 3,30. Artinya, Buku teks matematika berbasis IT tersebut telah memenuhi kriteriakevalidan. Mahasiswa yang mendapat nilai 
lebih dari 80 adalah 90.06\%. Dengan demikian nilai tersebut masuk dalam kriteria ketuntasan. Kemudian mahasiswa yang memberikan respon positif terhadap Buku teks matematika berbasis IT adalah 83.08\%. Dengan demikian nilai tersebut masuk dalam kriteria positif.

Selain dilihat dari hasil kevalidan dan keefektifan, terdapat beberapa hal yang harus di perbaiki oleh penulis pada saat menyusun Buku teks matematika berbasis IT ini . Diantara perbaikan yang harus dilakukan adalah buku Buku teks matematika berbasis IT yang tersusun dianggap kurang sistematis. Artinya isi dari buku Buku teks matematika berbasis IT ini masih sulit untuk dipahami oleh pembaca. Hal ini terjadi karena materi yang ditampilkan masih kurang rinci sehingga dianggap perlu untuk di susun kembali secara terurut dan benar. Hal ini sesuai pendapat Chomsin S. Widodo dan Jasmadi yang mengatakan bahwa "Guna mendukung ketercapaian, bahan ajar harus memuat materi pembelajaran secara rinci, baik untuk kegiatan maupun latihan"13.

Salah satu karakteristik mahasiswa matematika yaitu lebih banyak berkecimpung dengan dunia bilangan dan berhitung dari pada berkomunikasi. Terutama komunikasi dalam bahasa inggris. Kosakata yang mereka miliki tidaklah sebanyak kosakata Mahasiswa bahasa inggris pada umumnya. Saat pembelajaran, mahasiswa akan menyiapkan kamus bahasa Inggris, jika tidak memahami kata yang ada di dalam buku maka mereka akan segera membuka kamus, jika belum paham maka ia menanyakan pada lawan bicaranya. Hal ini memperkuat bahwa penyajian bahan ajar harus disajikan dalam bahasa yang sederhana. Sederhana bukan berarti menggeser makna. Buku yang baik menurut Abdul Majid adalah "buku yang ditulis dengan bahasa yang baik dan mudah dimengerti, disajikan secara menarik dan dilengkapi dengan gambar dan keterangannya"14.

Pengembangan buku teks pembelajaran matematika berbasis informasi teknologi berbahasa inggris telah dilakukan. Dengan melalui 4 tahap

13 Chomsin S. Widodo and Jasmadi, Panduan Menyusun Bahan Ajar Berbasis Kompetensi (Jakarta: Gramedia, 2008).

14 Abdul Majid, Perencanaan Pembelajaran Mengembangkan Standar Kompetensi Guru (Bandung: Remaja Rosdakarya, 2007). 


\section{Pengembangan Buku Teks Pembelajaran..}

pengembangan, buku teks yang dihasilkan telah dinyatakan valid dan efektif. Penyempurnaan terhadap buku teks yang dihasilkan dapat terus dilanjutkan dengan cara melakukan uji coba yang lebih luas lagi dengan melibatkan user yang lebih banyak atau dapat pula memadukan buku teks yang ada dengan beberapa media pembelajaran yang lain yang dianggap lebih relevan.

\section{Simpulan}

\section{Penutup}

Berdasarkan uraian pada hasil dan pembahasan tersebut, dapat disimpulkan bahwa Pengembangan Buku Teks Matematika Berbasis IT terdiri dari empat tahap, (1) Pendefinisian, (2) Perancangan, (3) Pengembangan, dan (4) Pendiseminasian. Buku Teks Matematika berbasis IT yang dihasilkan telah valid dan efektif berdasarkan penilaian para ahli dan melalui tes akhir mahasiswa serta lembar angket respon mahasiswa.

Saran

Setiap penulis hendaknya benar-benar mempersiapkan materi buku secara rinci dengan cara menguasai materi tersebut. Selain itu bahasa yang disajikan di dalam buku hendaknya dibuat sesederhana mungkin sehingga mudah dimengerti dan dipahami.

\section{Daftar Pustaka}

Abercrombie, Nicholas, Stephen Hill, and Bryan S. Turner. Kamus Sosiologi. Yogyakarta: Pustaka Pelajar, 2010.

A.M, Sardiman. Interaksi \& Motivasi Belajar Mengajar. Jakarta: Raja Grafindo Persada, 2006.

Berch, Daniel B., and Michele M. M. Mazzocco, eds. Why Is Math So Hard For Some Children?: The Nature and Origins of Mathematical Learning Difficulties and Disabilities. 1 edition. Baltimore, Md: Brookes Publishing, 2007.

Hudojo, Herman. Pengembangan Kurikulum Dan Pembelajaran Matematika. Malang: Universitas Negeri Malang Press, 2005.

Ianah, Ianah, and Hendri Raharjo. "Pengembangan Bahan Ajar Berbasis Komputer Dalam Pembelajaran Matematika Pada Pokok Bahasan Kubus Dan Balok." Eduma: Mathematics Education Learning and Teaching 3, no. 2 (November 14, 2014). https://doi.org/10.24235/eduma.v3i2.59.

Majid, Abdul. Perencanaan Pembelajaran Mengembangkan Standar Kompetensi Guru. Bandung: Remaja Rosdakarya, 2007.

Malalina, Malalina, and Nila Kesumawati. "Pengembangan Bahan Ajar Interaktif Berbasis Komputer Pokok Bahasan Lingkaran Untuk Kelas 
VIII Sekolah Menengah Pertama." Jurnal Pendidikan Matematika 8, no. 1 (2014): 55-70. https://doi.org/10.22342/jpm.8.1.1861.55-70.

Menteri Pendidikan Nasional RI. "Peraturan Menteri Pendidikan Nasional Republik Indonesia Nomor 2 Tahun 2008 tentang Buku." Biro Hukum dan Organisasi Departemen Pendidikan Nasional, January 4, 2008. http://kelembagaan.ristekdikti.go.id/wpcontent/uploads/2016/12/Isi-Permendiknas-2-thn-2008.pdf.

Sugihartati, Rahma, and Fitri Mutia. "Masyarakat Dan Perpustakaan Di Era Revolusi Informasi." Surabaya: Departemen IIP FISIP Universitas Airlangga, 2010.

Sungkono. Pengembangan Bahan Ajar. Yogyakarta: FIP UNY, 2003.

Titis, Anggraini. "Pengembangan Media Pembelajaran Interaktif Dengan Macromedia Flash Pada Materi Garis Dan Sudut Untuk SMP Kelas VII." Tesis, Universitas Negeri Malang, 2013.

Widodo, Chomsin S., and Jasmadi. Panduan Menyusun Bahan Ajar Berbasis Kompetensi. Jakarta: Gramedia, 2008.

Yasa, Gede Agus A. rya Saputra. "Pengembangan Bahan Ajar Online Mata Kuliah Micro Teaching dengan Model Borg \& Gall pada Program S1 Pendidikan Bahasa Inggris STKIP Agama Hindu Singaraja." Jurnal IImiah Pendidikan dan Pembelajaran Ganesha 1, no. 1 (2012). https://www.neliti.com/id/publications/207120/pengembanganbahan-ajar-online-mata-kuliah-micro-teaching-dengan-model-borggall. 